\title{
Counter-Manifesto: Student-Edited Reviews and the Intellectual Properties of Scholarship
}

\author{
Wendy J. Gordon†
}

In the great scheme of things, how important are the problems with law reviews? Jim Lindgren's essay is a bit overheated, even for someone enamored of polemic as a literary form. ${ }^{1}$ But he does have a point: if law reviews are going to be published, the task should be done better than it is. That does not mean getting rid of student law reviews. Not even for $\mathrm{Jim}^{2}$-but it does require patience and further inquiry into the nature of legal scholarship.

I join in several of Jim Lindgren's suggestions. Most important, authors' names and affiliations should be physically removed from articles before selection begins, as at least a partial prophylactic against good articles being ignored. ${ }^{3}$ In addition,

$\dagger$ Professor of Law, Boston University School of Law. Copyright ${ }^{\circ} 1994$ by Wendy J. Gordon. I began preparing this essay while I was Lecturer in Law at Yale Law School. I am indebted for discussion of this topic to many colleagues at both BU and Yale, as well as to Sam Postbrief, the editors of this Review, and the participants in the January 1994 AALS meeting convened to consider forming a new section on law reviews and legal scholarship. I should also note that I have a longstanding friendship with my antagonist here, Jim Lindgren, who has on occasion made excellent suggestions about my writing-for example, it was he who told me about Joseph Williams's useful book Style: Ten Lessons in Clarity and Grace (Chicago, 3d ed 1989)-and who has often provided both a willing ear and advice when law review editors were getting me down. Also, as I myself have never been guilty of any of the editorial sins that swarm through Jim's pageshaving never myself been among a law review's editors-I feel free to defend the latter with gusto.

1 See James Lindgren, Return to Sender, 78 CaI L Rev 1719, 1719 (1990) ("Polemics have a long and honorable history ....").

2 Jim's suggestions for improvement do not include elimination of the student-run law review. See James Lindgren, An Author's Manifesto, 61 U Chi L Rev 527, 535 (1994) ("Manifesto").

You may be wondering, why "Jim" rather than the expected "Professor Lindgren"? Law review criticism may be one of the few places where law review editors are willing to bend their usual rules, and here it's the customs of formality and distance that are giving way a little.

3 Conceivably a professor's school affiliation and prior scholarly output can provide a useful aid to student editors buried under piles of manuscripts. This is conceded by Jordan H. Leibman and James P. White, How the Student-Edited Law Journals Make Their Publication Decisions, 39 J Legal Educ 387 (1989), who nonetheless favor initial blind 
student editors should read several style books ${ }^{4}$ and be otherwise better trained before daring to correct others' prose. Further, faculty input into the publishing process should be increased, ${ }^{5}$ and more faculty-edited journals should enter the field. Also, more empirical research into the review process should be undertaken. ${ }^{6}$ But it seems to me that from what we know now, the virtues of the student-edited review outweigh its vices, from the perspective of all those it affects.

My essay will have two parts. The first will be a response to Jim Lindgren. The second will be a defense of one much-maligned aspect of student-run law reviews, their obsession with having authors provide background information and footnotes.

\section{A RESPONSE TO LINDGREN}

\section{A. Beneficiaries or Victims?}

A wide range of persons and institutions are potentially affected by law reviews. These include students, individual professors, the professoriat's pretensions to (or achievement of) meri-

reads to counter in-school favoritism and other undue influences. (Their article is one of the best addressing the question of law review restructuring.) As Leibman and White note, such procedures should be combined with methods to reduce the flood of manuscripts. See id at 418-20. See also Erik M. Jensen, The Law Review Manuscript Glut: The Need for Guidelines, 39 J Legal Educ 383 (1989). They should also be supplemented with methods to better select, educate, and coordinate the law review members who make article selections. See Leibman and White, $39 \mathrm{~J}$ Legal Educ at 420-22.

- I recommend Joseph Williams, Style: Ten Lessons in Clarity and Grace (HarperCollins, 4th ed 1994) and Robert Graves and Alan Hodge, The Reader Over Your Shoulder (Random House, 1979). The Texas Law Review Manual on Style (Texas Law Review Assoc, 7th ed 1992) is not suitable for providing such a general education, as two editors of the Texas Law Review themselves implicitly admit. See Charles D. Moody and Arthur S. Feldman, Greetings from Hell, 78 Cal L Rev 1703, 1704-08, 1716 (1990).

5 For one interesting suggestion on how this might be done, see Leibman and White, $39 \mathrm{~J}$ Legal Educ at 423-24. They suggest that the AALS organize willing faculty into a number of national panels, each with substantive expertise in a particular area and willing to review a certain number of manuscripts per year. Authors who wished to use the panels' services would be free to append the panels' evaluations and recommendations to their manuscripts when sending them to student reviews. "Ultimately, those reviews should prove to be influential, but probably not dispositive .... Like judges, the studenteditors would still have the final say, but now they would have the help of expert witnesses." Id at 424.

Leibman and White defer discussion of the details. How such a program would be administered, what kind of incentives would draw expert faculty to serve as reviewers, and similar questions, are issues that need to be hammered out. But the Leibman and White article is aimed more at putting the issue on the professorial agenda rather than at answering all questions.

B But note that my emphasis on which questions most need investigation is somewhat different from his. See text accompanying notes 8-9. 
tocracy, the bar and practicing judges, and society as a whole. Are they more likely beneficiaries, or victims?

\section{Students.}

Opinion is divided as to how much students gain from the current system. At many schools, students who do not make the review feel alienated, while students who achieve editorships often fail to attend classes. And after the first couple of spading assignments, the time spent on checking footnotes probably yields little marginal benefit to the student laborer. Further, some observers feel strongly that the students' learning/time ratio could be drastically improved if students turned the time spent on editing the articles of others toward writing additional papers of their own.

On the other hand, most student editors consider their review work a valuable learning experience. ${ }^{7}$ Admittedly, cognitive dissonance may be partially responsible for their view. (Those who feel themselves required to jump through resume-enhancing hoops are more likely than outsiders to assign a transcendent value to hoop-hopping.) Nevertheless, student perception that being on law review provides valuable learning experience strikes me as accurate.

Membership on a law review is one of the few forms of apprenticeship left in our profession. (Clinic participation is another.) These activities put students into unusually close contact with expert professionals, and in a context where the latter really care not only about the process (in which, as teachers, they may try to show tolerance and flexibility) but also about the outcome. Such benefits should not lightly be foregone. Working with author/lawyers, students often learn not only subtleties of legal thinking that might not be available outside such one-on-one contact, ${ }^{8}$ but they may also learn what they should have known earlier-that details count and that sloppiness is intolerable.

If the outcome is sometimes an excessive concern with form and detail-how does the footnote look?-surely the alternative is worse. And over time, as these students on reviews go out into

7 Max Stier, et al, Law Review Usage and Suggestions for Improvement: A Survey of Attorneys, Professors, and Judges, 44 Stan L Rev 1467, 1491-92 (1992). By no means are all students happy with the experience, however. See, for example, an article by a former student editor, E. Joshua Rosenkranz, Law Review's Empire, 39 Hastings L J 859 (1988) (by implication).

8 Such contact is also available in seminar papers. 
practice, the obsessions will moderate and leave behind a healthy respect for precision.

At least that is my current estimate and hope. My discussion necessarily rests on many assumptions for which evidence is scarce. I therefore echo one of Jim's recommendations, that more empirical research be done and made accessible, on a variety of law-review related pedagogic questions.

For example: How would overall student morale, class attendance, and productivity change if students ceased editing the law reviews? How many student editors do indeed feel the process valuable, and for what purposes? If student note-writing and editing were eliminated, how many additional opportunities to write papers (in close consultation with professors) would be available to the released students? Do the law reviews enroll only an elite who already know the value of precision? How many students on the law reviews deal in depth with author/lawyers, and what percentage of students in law school join reviews?

Some of this data is available in scattered form at individual law schools; some is collected; ${ }^{9}$ much is not; and, so far as I know, no overall compendium of the existing data exists. Until I have better answers to these and similar questions, my best estimate is that, from the perspective of furthering student learning, student-run reviews provide a net benefit to students.

\section{Individual professors, as authors and consumers.}

In our capacity as authors, student editors drive us crazy. I actually suspect that the stress caused by their overshort deadlines ("respond to our edit in three days or we'll print it OUR way") has caused health problems. The line-editing of prose is, as Jim indicates, usually maddening and time-consuming, and often more destructive than helpful.

But as Jim fails to indicate, the student editors sometimes recommend tremendously helpful structural changes. On one occasion I had reworked a lengthy article through more than five drafts over eight years: the first time I presented it to a faculty colloquium was in 1985, and by 1993 the article was a verbal thicket. Only the constant admonition of my student editor-to simplify, simplify, simplify-finally made the article's argument linear and satisfactory. ${ }^{10}$ Indeed, nearly every one of my articles

9 See, for example, Leibman and White, $39 \mathrm{~J}$ Legal Educ 387 (cited in note 3); Stier, et al, 44 Stan L Rev 1467 (cited in note 7); and the sources collected in Manifesto at 532.

${ }^{10}$ Note, however, that $I$ did the simplifying myself. I do not know if I would have 
has been stronger coming out of the editorial process than it was going in.

In our capacity as consumers of scholarly articles, it is customary to complain that law reviews contain nothing but deadening prose and overstuffed style. ${ }^{11}$ Admittedly, the literature contains many rambling pieces that could do with a top-notch edit and shrink treatment, and funny articles (like those by Pierre Schlag or-gasp-Jim Lindgren) are all too few. But in reading many law review articles, I actually enjoy myself. I even like footnotes. ${ }^{12}$ Because they provide an author the opportunity to conduct a sort of running dialogue with herself, footnotes sometimes give me the feeling that I am looking through a window into someone's head as she composes.

\section{The meritocracy.}

Jim's Essay shows a concern that a scholar's affiliation with an elite school might prejudice the process by which articles are selected. However, neither his publishing record nor mine suggests that only teachers at Ivy League schools are able to place articles well. Still, many researchers have reported that bias exists, particularly reflecting some student temptation to favor their own (in-house) professors. ${ }^{13}$ Therefore blind reviewing (deleting the name and other identifying data from each article submitted), which is common in other disciplines, should become the rule in law reviews as well, at least at the initial stages of article selection.

There is an aristocracy in the law school world which can lead to undervaluing the work of outsiders; this should be resisted to the extent possible. In addition to blind review, another mode of resisting the aristocratic tendency is to insist on full recognition of prior scholarship on a given topic. As discussed below, the law reviews already engage in this practice. Further, it may be that the students are less dominated by "methodological and intellectual orthodoxies"14 than peer review journals in

been as pleased if the editor had made the changes.

11 The classic here is Fred Rodell's exuberantly curmudgeonly piece in the Virginia Law Review, reprinted and supplemented in his Goodbye to Law Reviews-Revisited, 48 Va L Rev 279 (1962).

12 Honest.

13 See, for example, Leibman and White, $39 \mathrm{~J}$ Legal Educ at 405.06 (cited in note 3).

14 K.R. St.Onge, The Melancholy Anatomy of Plagiarism 29-30 (University Press, 1988). Lindgren also notices this. See Manifesto at 534-35. 
some disciplines sometimes seem to be. This too may work to open the journals to new voices.

\section{Judges and the bar.}

Fred Rodell argued that lazy lawyers use law review articles to collect cases and arguments. He saw something wrong with that. ${ }^{15}$ I am at a loss to understand what he had against the practice, other than his disapproval of lazy lawyers whose selfinterest might lead them to support modes of legal scholarship which Rodell disdained. But if law reviews can make even lazy lawyers better lawyers, two cheers. And if as a result judges are better informed, three cheers.

It has also been argued that taking the law reviews away from students would make the reviews so theoretical that lawyers and judges would stop reading them. I think that is a possibility.

\section{Society at large.}

As Rodell saw, perhaps the most important problem with law review articles is the ivory-towerism of professors-the likelihood that the professoriat will talk primarily to itself, caught in legalisms and ignoring the real world. ${ }^{16}$ But we have made progress since Rodell first wrote. The Legal Realist movement and its progeny-movements such as Law and Economics, Critical Legal Studies, and Law and Society-have forced us to expand our frame of reference beyond the four corners of cases.

Insularity is, of course, something we still need to fight. These movements have introduced their own islands of discourse. CLS writing tends to be in a language best understood by CLS initiates; Law \& Economics articles tend to speak most clearly to Law \& Economics folk; and so on. Removing students from their editorships, so that we talk only to each other prior to publication, is hardly likely to ameliorate this problem.

\section{B. Specific Responses}

My primary disagreement with Jim Lindgren's article is one of emphasis. On the whole I like rather than dislike the system of student-run law reviews. As mentioned above, however, the

15 Rodell, 48 Va L Rev at 285-86, 287 (cited in note 11).

16 See id at 283-84. 
institution could be improved, and many of Jim's suggestions are good ones. One suggestion, however, is not. Jim calls for more specialization in journals. ${ }^{17}$ To the contrary, I think that what the professoriat has to offer is the ability to cross subject-matter and doctrinal lines, and to utilize the interrelationships that exist in the real world. A drastic increase in the number of specialized journals might work against this possibility.

As for the empirical details of Jim's article, most are unexceptionable. A few are otherwise. The data he cites on student interviewers have no necessary relevance to the topic at hand, ${ }^{18}$ and his pointing to faculty teaching areas as an indicator of research interests seems of dubious value, particularly given the mandatory concentration of teachers in the first-year curriculum. ${ }^{19}$ But these are minor cavils. It is good that Jim is working to put our scholarly institutions on the professional agenda.

\section{ON Praising PREDEcessors}

\section{A. Footnotes and Literature Reviews}

Perhaps the most common criticism of law reviews (other than those Jim makes) is the complaint that the students are too obsessed with "prior art." This obsession shows itself in two ways. First, most articles are expected to contain a lengthy introductory section where the author summarizes the relevant case law and literature from which her topic has arisen. Second, most articles are expected to contain a great many footnotes.

As for the inclusion of introductory background sections, many professors feel these sections do little more than cater to law review editors' ignorance, at fairly high cost. These costs include: increasing the time needed to write an article and thus decreasing the number of contributions to the literature one can make; increasing the time needed to read an article and thus decreasing readership or unnecessarily sapping valuable eye time; increasing an article's length and thus reducing the number and diversity of articles that can be published; increasing the boredom level of the law review literature; and increasing the

17 Manifesto at 536. Leibman and White make a similar suggestion, citing additional reasons, $39 \mathrm{~J}$ Legal Educ at 421-22 (cited in note 3).

${ }^{18}$ See Manifesto at 537.

19 Id at 532 (noting a discrepancy between journal subject matter and subjects most frequently taught). It is unclear how this pattern disserves faculty interests; even if most journals do not publish many articles in often-taught subjects, faculty writing and teaching interests are frequently not the same. 
chance that the author's central ideas will be lost amid discussion of ancillary matters. The complaints about footnote costs are parallel.

It is clear that both literature reviews and footnotes can be overdone. But on balance, I think it a good thing that most of our journals require both. ${ }^{20}$ First, placing the article in context helps the student editors select more wisely. (Hopefully they will do a preemption check before accepting a piece, which should also assist them in making an educated choice.) Second, placing the article in context-even though the students may not fully recognize when this is well or poorly done-means that our articles are accessible to a fairly wide audience. If I want to learn about a new area, I can do so by picking up virtually any article. ${ }^{21}$

This is far different in fields whose journals are solely edited by faculty. In philosophy, for example, it is not uncommon for a lawyer-reader to be somewhat mystified when reading an article. The author typically assumes his or her readership knows precisely with whom the article is arguing and over what topic. The writer may not even bother to identify either, never mind explaining the literature as a whole.

Of course, while most articles in the faculty-edited journals of other disciplines omit discussion of background, such journals do publish occasional articles whose sole purpose is to review the literature on a given topic. Conceivably, we could follow that model. Nevertheless, the current format of instant access to background is useful to us because of the high number of interrelated fields within law. "[S]cholarship directed at narrow interests will often generate interest and válue in unexpected places." ${ }^{22}$ Also, as Tocqueville argued, lawyers in our country possess a special kind of influence; ${ }^{23}$ as such we have a special responsibility to make ourselves understood. ${ }^{24}$

Further, it is all too easy to spend our time reinventing the wheel. We all know that even pygmies see further than ordinary

20 It is also a good thing that not all do.

21 The same may not be true for non-lawyers.

22 See Leibman and White, $39 \mathrm{~J}$ Legal Educ at 422 (cited in note 3).

23 See Alexis de Tocqueville, Phillips Bradley, ed, Henry Reeve trans, Democracy in America 272-80 (Alfred A. Knopf, 1963). For being reminded of lawyers' special role in this connection, I am indebted to Richard Ford.

${ }^{24}$ Compare Linda Hirshman's suggestion that "[a]s virtuous rulers of the law schools, law teachers have a responsibility to enable the ruled to participate in the regime." Linda R. Hirshman, Nobody in Here But Us Chickens: Legal Education and the Virtues of the Ruler, 45 Stan L Rev 1905, 1929 (1993) (developing and applying a virtue-based ethic). (I am also indebted to her for bringing to mind the Tocqueville material.). 
mankind when "standing on the shoulders of giants." An insistence on knowing where we have come from will make it more likely that we and our readers will know when we are saying something new.

Admittedly, some scholars and some faculties have profited by ignoring this: they trust that if they occasionally err by unknowingly repeating prior art, this will be more than outweighed by the increase in the number of articles they can write and ideas they can advance. This viewpoint might prevail with me, except for the role that acknowledging the past plays in safeguarding the meritocratic elements of our profession.

B. The Intellectual Property Regime of Scholarship: The Role Played by Background Exposition and Footnotes

The intellectual property regime that governs scholarship is probably the best-functioning regime that we currently have for governing intellectual products. For purposes of contrast, note the problems inherent in the most salient alternative regimes: a property regime, a liability-rule regime, ${ }^{25}$ a regime of public subsidy, or a regime of advertiser support. Every regime except that of scholarship poses intractable trade-offs between economic and noneconomic incentive effects, administrative costs, and free speech.

To illustrate, consider a property regime like copyright. It provides incentives at a relatively low level of administrative cost. But it poses the dangers that culture will be subordinated to popularity and that intellectual-property owners will use their exclusive rights to engage in private censorship. ${ }^{26}$ Thus Disney has successfully silenced a parody of which it disapproved, the United States Olympic Committee has used its trademark to

${ }^{25}$ The term "liability rule" is of course derived from the classic article, Guido Calabresi and A. Douglas Melamed, Property Rules, Liability Rules, and Inalienability: One View of the Cathedral, 85 Harv L Rev 1089 (1972). In a liability-rule regime, intellectual property owners would lack a full property-rule veto over the uses that might be made of their property, but they would be able to obtain governmentally-set compensation for uses to which they did not consent. Allowing a damage-only remedy is a form of liability rule, as is a compulsory license.

${ }_{26}$ Note that even from an economic perspective, using property for purposes of censorship is less justifiable than are most other uses of property. See, for example, Wendy J. Gordon, Toward a Jurisprudence of Benefits: The Norms of Copyright and the Problems of Private Censorship, 57 U Chi L Rev 1009, 1042-43 (1990) (review essay) (arguing that in situations involving highly personalized and emotional investment, there is often no "highest valued use" that can be determined independently of the legal allocation of entitlement starting points). 
force the Gay Olympics into changing its name, and J.D. Salinger was able to keep out of book stores a biography that quoted from letters he had deposited in university libraries. ${ }^{27}$

A liability-rule regime such as compulsory licensing avoids the danger of private censorship. However, such systems may involve insuperable administrative costs that could overwhelm incentive effects. ${ }^{28}$ Governmental subsidies can restore some positive incentive for production, but they pose the danger of public censorship. Advertiser-sponsored dissemination (as on TV or in magazines) provides incentives and conceivably might be structured to avoid censorship by any one particular person, but it poses the danger of a lowest-common-denominator cultural product that is constructed to be noncontroversial and thus fundamentally uninformative.

By contrast, what governs scholarship is a set of informal rules that avoids the censorship problem without incurring great administrative costs or sacrificing incentives. All of us can use others' ideas, and sometimes even language, without the author's advance permission: all we need "pay" is a citation or other recitation of our debt. ${ }^{29}$ This system works for scholarship due to the fortunate confluence of several factors. In particular: first, we each "pay" by registering our debts in footnotes; second, the schools in turn "pay" those who are most commonly cited. They award tenure, increase salaries, and give offers at prestigious places to oft-cited folk. Censorship is avoided both because tenure protects the proponents of unpopular views, and because the people who pay the money are not the only people who decide which scholars are best. Of the various intellectual property regimes, only the scholarship system can make a plausible (if highly imperfect) claim to preserving both high incentives to produce and a freedom to create virtually unimpeded by predecessors' property claims.

27 See Walt Disney Productions v Air Pirates, 581 F2d 751 (9th Cir 1978); San Francisco Arts \& Athletics, Inc. $v$ United States Olympic Committee, 483 US 522 (1987); Salinger $v$ Random House, Inc., 811 F2d 90 (2d Cir 1987). For consideration of these and other attempts to use intellectual property for purposes of censorship, see Wendy $\mathrm{J}$. Gordon, A Property Right in Self-Expression: Equality and Individualism in the Natural Law of Intellectual Property, 102 Yale L J 1533, 1535-46, 1583-1606 (1993).

${ }_{28}$ See Wendy J. Gordon, Fair Use as Market Failure: A Structural and Economic Analysis of the Betamax Case and its Predecessors, 80 Colum L Rev 1600, 1622-24, 163235 (1982). See also Gordon, 102 Yale L J at 1773-76, and sources cited therein.

${ }_{29}$ Which reminds me to thank Patricia Diak (Yale class of 1994) whose enthusiastic research for a seminar paper on plagiarism spurred me into focusing on the value of footnotes as a method of intellectual property payment. 


\section{CONCLUSION}

In response to Jim Lindgren's review essay, this brief article has presented a qualified defense of student-run journals. It has also suggested that certain practices of those journals are crucial to the success of the relevant intellectual property regime in promoting both substantive progress and meritocracy.

P.S. This Essay was inspired by appreciation of the student editors who have made significant contributions to my published work, primarily Pat Cipollone, Claire Finkelstein, Susan Pilcher, Adam Pritchard, Myron Rumeld, and Gene Scalia. I have not had the opportunity to thank any of them in public before. ${ }^{30}$ Thanks, guys.

30 Though on a couple of occasions I've tried to sneak the name of my editor into the thank-you footnote, the reviews have refused. So I would like to take this opportunity also to thank two wonderful non-student editors I've worked with: Richard Epstein and Theresa Glover. 


$$
\text { , }
$$

